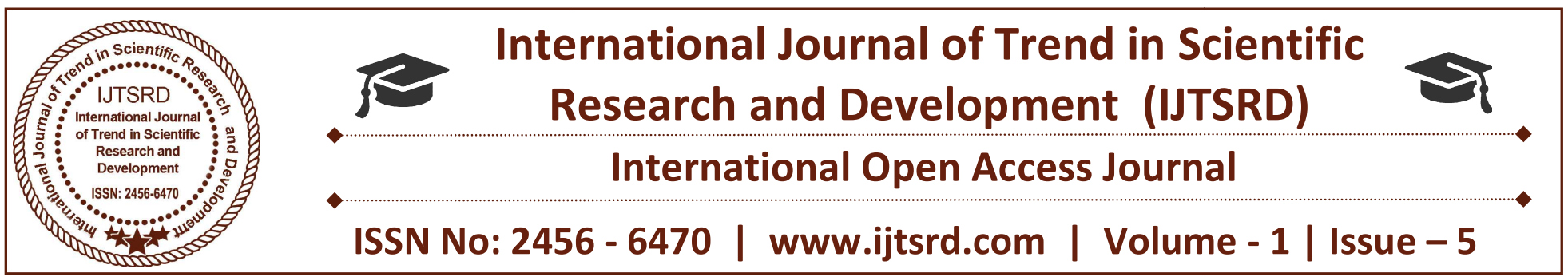

\title{
Rural Electrification by Solar Power LED's
}

\author{
Dr. D.R.V.A.Sharath Kumar \\ Professor, Dept. of ECE, St.Martins Engineering \\ College, Hyderabad
}

\author{
Mr. J. Nageswara Reddy \\ Asistant Professor, Dept. of ECE, CMR College of \\ Engineering \& Technology, Hyderabad
}

\begin{abstract}
Around 25,000 villages are located in remote and inaccessible areas and hence could not be electrified through conventional grid extension in India. The functionality of the system varies across the placed and across the seasons. During rainy season on an average one luminary works 2 to 3 hours. During winter and summer on an average one luminaire works 4 to 5 hours. However, performance declines over the years. Use of kerosene is reducing in rural areas. Nearly 53 to 69 percent reported that there is significant improvement in their children's education, and 37 to 78 per cent reported that there is improvement in the standard of living after the installation of solar lighting by LED's. Beneficiaries now spend more time on income generating activities. Crime rate has also declined due to availability of solar street lights in the village. A basic system consists of a small solar panel, a battery, a charge controller, LED lights, and a universal outlet for charging cell-phones or other small appliances. This approach differs from the many for-profit organizations, who use conventional business strategies, simply importing their technology and sell the product with financing to those who can afford it. My community centered capacity building strategy differs from current industry players in that it allows for increased local capacity and empowerment.[1].
\end{abstract}

Keywords: Solar Panel, LED Lighting System, Pole, Batteries, Charge Controller, Inverters and Cooling Box

\section{INTRODUCTION}

Lack of access to electricity is one of the biggest issues facing the world's poor, with over 1.6 billion left in the dark globally. The vast majority of these people lives in rural areas of developing countries because they are too poor and may be in too remote a location to be reached by the national grid. For their lighting needs they rely on candles, kerosene lanterns, and firewood. This results in a daily expense that is expensive in the long run. Furthermore, this type of indoor lighting causes indoor pollution and chronic lung problems. Long-term, solar energy is the most practical and economical way of bringing power to poor and remote communities.

The vast majority of these people live in rural areas of developing countries, where scarce of government investment and difficult geography keep the national electric grid from extending to their villages. Investment in transmission lines is expensive, especially when a village is far away from a large city or in the mountains. Poor villages without electricity face greater difficulties in meeting needs such as food, shelter, and entertainment. They must do so with forms of energy other than electricity. Candles and kerosene lamps that emit toxic fumes damaging to the lungs are commonly used for lighting. Firewood is commonly used for cooking, which can further contribute to indoor pollution, and refrigeration is not an option. Studying after dark to dim, flickering candle lights and kerosene lamps is difficult for children, and businesses usually cannot continue operating after dark. 
International Journal of Trend in Scientific Research and Development (IJTSRD) ISSN: 2456-6470

\section{Definition of the problem:}

Small-scale distributed solar home generation systems offer a solution to these energy issues. A solar home system (SHS) can be installed and function almost anywhere there is sunlight. They can provide electricity for services such as lighting, television, cell phones, fans, cooking, refrigeration, and more. Furthermore, storing the electricity in a battery will allow electricity to be used for hours into the night. While there are companies already doing this in rural areas, the need is vast and all over the world. The problem is being addressed in small pockets all across the globe, but this is only a small dent compared to the total amount of people without electricity. Solar micro grid system consists of a set of solar photovoltaic panels or solar thermal collectors for electricity generation, a battery pack for charging and storage of electricity for night or anytime when sun is not there and small scale version of the centralized electricity system, established by the community being served. They achieve specific local goals, such as reliability, carbon emission reduction, diversification of energy sources, and cost reduction, etc. For the problem to be addressed, many more social enterprises distributing SHS's will need to be set up in countries all across the world. A village would be declared as electrified, if Basic infrastructure such as Distribution Transformer and Distribution lines are provided in the inhabited locality as well as the Dalit Basti hamlet where it exists.Electricity is provided to public places like Schools, Panchayat Office, Health Centers, Dispensaries, Community centers etc. The number of households electrified should be at least $10 \%$ of the total number of households in the village.[2]-[3]

\section{International Status:}

Off-grid systems are not new. For decades they have been used to supply remote areas (e.g., rural villages, islands and even small cities) that are not connected to any national electricity grid. For renewable, in particular solar PV, applications in off-grid systems were more common than grid-connected systems until 1995. Furthermore, mini-grids are used to supply remote industrial sites, telecommunication facilities or public applications [4] (e.g., lighthouses, national parks, schools or mountain shelters) (Werner and Brayer, 2012). The market can be divided into six categories (adjusted from Schnitzler, et al., 2014, which is also the categorization used by a number of market reports):

$>$ Islands;

$>$ Remote systems;

$>$ Commercial/industrial - to ensure energy security (99.99\% reliability) or provide cheap energy sources, especially if connected to heat production;

$>$ Community/utility - often demonstration projects in the case of developed countries;

$>$ Institutional/campuses - includes hospitals, government buildings and other institutions with access to cheap capital and no short payback requirements.

> Military - US-specific market for 500 military facilities within and outside of the US.

Global analyses of off-grid renewable energy systems are scarce, but some data on global overview of micro-grids, off-grid systems and diesel generators do exist. Many of these overview reports are from market research companies. Navigant Consulting, one of these market research companies, distinguishes between micro-grids and minigrids. Its latest microgrid report identified $4393 \mathrm{MW}$ of total installed micro-grid capacity in mid-2014 (Navigant, 2014a). Only $53 \%$ of this capacity is actually in operation and an additional two GW of micro-grids are in the planning or proposal stage. Furthermore, the majority of micro-grids in the United States are run on gas. In addition to the micro-grid capacity, an additional $8900 \mathrm{MW}$ of nano-grid capacity (from $5 \mathrm{~kW}$ remote systems to $100 \mathrm{~kW}$ grid-tied systems) was identified in 2014 (Navigant, 2014b). In comparison, BSIA identified a total of $3.5 \mathrm{GW}$ of global installed capacity in 2012 (BSIA, 2012). The major difference is the installed capacity in Europe $(1.2 \mathrm{GW}$ vs 0.54 GW). Similarly, GTM research (2014) identified a total micro-grid capacity in North America of $355 \mathrm{MW}$ in 2014, while Navigant's data suggest a widely disparate capacity of $2874 \mathrm{MW}$.[7]

In general, North America is the world's leading offgrid market, with an additional planned or proposed capacity of $1363 \mathrm{MWe}$ or $66 \%$ of the global total. The largest growth took place in the Asia-Pacific Region with 134 of the 155 micro-grids being built during 2013 alone (Navigant, 2014a).

Islands and remote systems are an important market and opportunity for off-grid renewable energy 
International Journal of Trend in Scientific Research and Development (IJTSRD) ISSN: 2456-6470

systems. For islands or rural areas where the mini-grid infrastructure is already in place, there is the economic case to displace - or ensure more efficient use of - diesel generators (ARE, 2011). The 37 Small Island Developing States (SIDS) had a total installed capacity of $28.4 \mathrm{GW}$ at the end of 2012 (IRENA, 2014a). This included 10.2 GW for Singapore, around $5 \mathrm{GW}$ each for Cuba and the Dominican Republic. This left around $8 \mathrm{GW}$ for all other SIDS. But there are also other island power systems that are not part of SIDS. Worldwide, there are 2056 islands with 1000 -100000 inhabitants each, with an average electricity demand of $25.6 \mathrm{GWh}$. That equals around $12 \mathrm{GW}$ of capacity (Blechinger et al., 2014). Many of these island systems are hybrid mini-grid systems with some level of renewable energy.

Beyond islands, global statistics on rural electrification through off-grid systems (either based on diesel or renewable) are limited, although a number of countries are collecting or reporting national data. Recent estimates suggest a current market potential for upgrading existing diesel-based, off-grid systems with renewable in the range of 40$240 \mathrm{GW}$. Renewable energy could meet almost half of global energy demand by 2050 according to the International Energy Agency's ambitious BLUE MAP scenario published in Energy Technology Perspectives 2008. Under this scenario, world greenhouse gas (GHG) emissions are halved. Renewable energy sources have a huge contribution to make in creating a sustainable energy system. They help to mitigate climate change, increase the security of our global energy supply system and give developing countries access to affordable energy in support of the UN Millennium Development Goals. The BLUE Map scenario in the International Energy Agency's 2008 Energy Technology Perspectives Report (IEA, 2008a) was developed to secure a 50\% reduction in global CO2 emissions by 2050 . According to the IPCC (2007), however, emissions must be reduced by $50-85 \%$ to keep global temperature increases between $2^{\circ}$ and $2.4^{\circ} \mathrm{C}$. Under the BLUE Map scenario, biomass accounts for around $23 \%$ of total world primary energy in 2050 and becomes the most important energy source. Solar power and wind provide $11 \%$ and $12 \%$ of global electricity production respectively[6]

\section{National Status:}

Rural electrification is the process of bringing electrical power to rural and remote areas. Electricity is used not only for lighting and household purposes, but it also allows for mechanization of many farming operations, such as threshing, milking, and hoisting grain for storage. The concept of solar LED's mini-grids in India was pioneered in the 1990s in the Sunder ban delta region in the state of West Bengal and in the forested region of Chhattisgarh state (then part of Madhya Pradesh state). A solar PV power plant of $25 \mathrm{kWp}$ capacity was installed in 1996 by WBREDA in Kamalpur village (Sagar Island), which continues to energize the village to this day. Thereafter, mini-grids connected to solar PV, biomass or small hydro, have been implemented in various states, notably Bihar, Chhattisgarh, Lakshadweep, Madhya Pradesh, Odisha, Uttar Pradesh, Uttarakhand and West Bengal. Depending on their capacity, Solar LED's provide electricity for households, small commercial activities, for community requirements such as the supply of drinking water, street lighting, vaccine refrigeration, and schools. While the Ministry of Power is the nodal ministry for the extension of the centralized grid electrification system in the country, it has also been instrumental to promote renewable energy-based mini-grids(Solar LED's) to electrify remote and far-off areas. The MNRE started promoting mini-grids under the off grid electrification programmes during the late nineties and early part of 2000 to cover villages that are unlikely to be covered through grid extension. The diesel based mini-grids were also in operation during the 90's in many of the remote villages in hilly states of north-eastern region of India, but have been subsequently discontinued by the power departments of the respective states with increase in prices of landed diesel to such remote areas (Kumar et al. 2007) remote villages (out of approximately 693,732 villages as per Census 2001), which will be difficult to connect through gridsupplied systems. Therefore, renewable energy-based solar LED's or stand-alone systems were considered to electrify these identified remote villages. Many of these remote villages have now been provided with renewable energy-based mini-grids or stand-alone systems such as solar home systems. Specifically, the Remote Village Electrification Programme (RVEP) and the Village Energy Security Programme (VESP) under MNRE electrified more than 12,700 remote villages and hamlets (MNRE 2013). The two most successful models of mini-grids implemented by government agencies in India are those implemented by WBREDA and CREDA. WBREDA has set up more than twenty mini-grids based on solar power 
plants with an aggregated capacity of around $1 \mathrm{MWp}$ supplying stable and reliable electricity to around 10,000 households in West Bengal. CREDA, on the other hand, has electrified around 35,000 households across more than 1400 villages and hamlets with low capacity (1-6kWp ) solar mini-grids in Chhattisgarh. In addition, biomass gasifier-based mini-grids were also implemented under the VESP (in around 80 villages across different states in India) or by research institutes and NGOs such as TERI Indian Institute of Science and Development Alternatives. [5]-[6]

Indian Institute of Science and Development Alternatives.

\section{Importance of the proposed project in the context of current status:}

About $30 \%$ of India's people (77 million households which is around 360 million people) lack adequate access to electricity- a number we could eventually connect via cheaper, cleaner and more reliable renewable sources. A sustainable and scalable model is essential to allow hundreds of millions of people many of whom have to rely on expensive and dirty kerosene lamps for lighting - in India and elsewhere in the world to access affordable, low carbon, renewable energy. In addition to providing access to suitable renewable solar energy by LED's to rural consumers, addressed the challenges of scaling up clean energy solutions to benefit large numbers of people by developing viable financial mechanisms, and also helps Indian businesses and communities lead and benefit from the emerging global low carbon economy. I identified that access to energy is one of the basic requirements for escaping the poverty trap and, although the conventional grid has reached almost all villages in India, millions lack access to reliable and affordable lighting.[1]-[2]

More than 10 lakhs people in metropolitan city Hyderabad alone - still live without electricity. The Government of Telangana and India has provided number of subsidies in grants and funds to support rural electrification through renewable energy (Solar Power by LED's) for more than two decades, yet the current system lacks efficiency and doesn't encourage long-term success. Due to an array of factors, rural poor communities oftentimes are provided with 'band-aid' solutions for electrification that result in short-term achievements, but lead to break-down over the long-term. Based on more than a decade of experience in the field throughout developing regions of the world, we believe several elements need to present if sustainability and longevity of rural solar PV systems can be reached technically, socially and financially. Despite the abundance of inefficiencies seen by the private sector within the current donor-led system of rural electrification, solutions and improvements are available. With an emphasis placed on the need for high-quality technologies and longterm solutions, the following pieces are critical to achieving technical, social and financial longevity of rural PV systems

The public sector needs to consult with off-grid experts. Previously some of the organizations had identified several sustainable off-grid business models with high potential to scale up. Debt financing has been found to be the primary unmet need in the offgrid sector (Solar Power LED's). To build on our learning and help fill this critical financing gap. With this I want to conclude that to fill the above mentioned gap, more number of rural areas are to be electrified by solar power LED's.[11]

\section{Analysis on cost constraints}

Analyzing lighting expenditures from the customer perspective is important in order to understand the cost constraints that would make the new design "affordable" for users in INDIA. In the context of low-income customers of the Hyderabad people, "the degree to which a firm's goods or services are affordable to [base of the economic pyramid] consumers"; noting also that due to the cash flow constraints of daily wages, for many low-income households the upfront cost is the real barrier. In this project the assumptions are to be made about affordability based on customers' costs of using existing alternatives, and validated this with informal interviews. For kerosene and candles, average household expenditures as per survey are from $\$ 2.63$ $\$ 4.64$ per month; these expenditures represent operating costs and do not include the initial investment cost of purchasing a lantern. In and around rural areas of Hyderabad average monthly household operating costs ranging from $\$ 8-\$ 10$ per month, with insignificant difference between candle users and kerosene users. Most households report using multiple instances of either kerosene lamps or candles, typically with one instance in each room being lighted. In the surrounding rural areas of Hyderabad, most users of kerosene and candles are aware of the high operating costs they pay compared to those with grid electricity. Compared to solar-powered lights, the 
International Journal of Trend in Scientific Research and Development (IJTSRD) ISSN: 2456-6470

barrier to entry for kerosene or candles as initial investment cost is low enough to make them accessible to even the very poor. Based on the above constraints it is necessary to be concentrated on the user preferences, performance specifications, and cost constraints, and it will be plugged these into a basic user-centered design approach, whereby the needs and preference of the user serve as the foundation for design decisions. Because the underlying technology used in solar portable lights will well understand, the design challenge is to be determined an optimal form factor and then will select the combination of components that most effectively will produce the required performance within the cost constraints. [6]

\section{Overall System Design:}

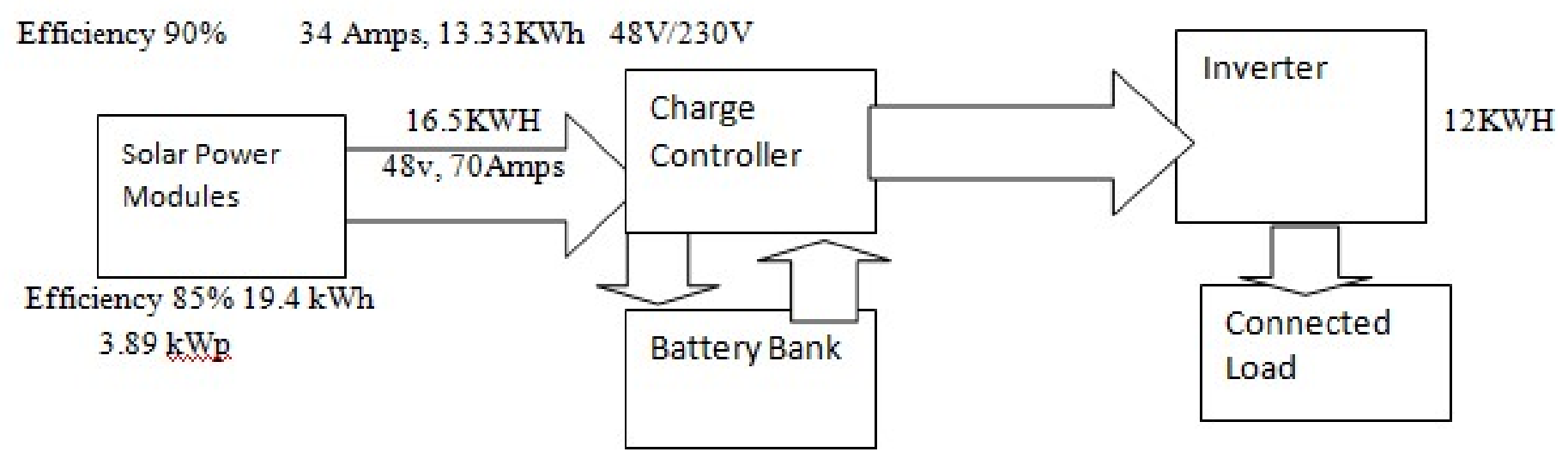

\section{Work Plan: Methodology:}

Solar Panels exposed to sunlight will be fitted on the electric pole which is of 16 feet height. The power generated by the solar panels will be stored and used to light the LEDs that are fitted into a focusable dome so that the light emitted by LEDs are properly focused and the required area is covered in the villages. The same setup is installed more in number depending on the requirement. As a pilot project, ten Solar Powered LEDs with supporting circuit and electric poles will be installed in the Bahudurapally village near to the college. Later on the project can be extended to other nearby villages.

The team used both primary and secondary data to inform its understanding of user preferences around lighting, including current lighting usage habits, lighting expenditures, and general preferences toward form and functionality. The secondary data included comprehensive, country-specific quantitative and qualitative research studies conducted and published.[11]
Given table gives list of Villages to be visited.

\begin{tabular}{|l|l|l|}
\hline $\begin{array}{l}\text { Name of the } \\
\text { Village }\end{array}$ & \# Respondents & Method \\
\hline Dhulapally & 200 & Interview \\
\hline Bahadhurpally & 200 & Interview \\
\hline Suraram & 200 & Interview \\
\hline
\end{tabular}

Table shows Sampling of different light sources and lumen output:

\begin{tabular}{|l|l|l|}
\hline Light source & Power & Luminous flux \\
\hline $\begin{array}{l}\text { Incandescent light } \\
\text { bulb }\end{array}$ & $100 \mathrm{~W}$ & 1700 lumens \\
\hline $\begin{array}{l}\text { Fluorescent tube } \\
\text { light T8 }\end{array}$ & $32 \mathrm{~W}$ & 3000 lumens \\
\hline $\begin{array}{l}\text { Fluorescent } \\
\text { lantern }\end{array}$ & $6 \mathrm{~W}$ & 340 lumens \\
\hline LED flashlight & $1 \mathrm{~W}$ & 40 lumens \\
\hline $\begin{array}{l}\text { Kerosene wick } \\
\text { lamp or candle }\end{array}$ & $\mathrm{n} / \mathrm{a}$ & 8 lumens \\
\hline
\end{tabular}

The idea to be projected that the design should include a "smart" circuit and charging function, which protects the battery from overcharging, deep discharge, and accidental discharge. This functionality 
International Journal of Trend in Scientific Research and Development (IJTSRD) ISSN: 2456-6470

prolongs battery life, and because replacement batteries constitute the only operating cost of the product, has a significant effect on total cost of ownership.

Table of Key components in the product design.

\begin{tabular}{|c|c|}
\hline Element & Considerations \\
\hline Solar cell & $\begin{array}{l}\text { - Must deliver sufficient power to } \\
\text { charge } 1.2 \mathrm{~V} \text { battery in } 5.5 \text { hours of } \\
\text { average peak sun hours in Zambia } \\
\text { - Resistance in wiring can be } \\
\text { significant at low voltages and must } \\
\text { be accounted for } \\
\text { - Epoxy-coated solar cells yellow } \\
\text { with exposure to sun, decreasing } \\
\text { efficiency within } 2 \text { years; PET- } \\
\text { laminated lasts longer but has higher } \\
\text { cost }\end{array}$ \\
\hline Battery & $\begin{array}{l}\text { - Charging capacity should be } \\
\text { oversized from daily requirements in } \\
\text { order to provide a buffer for cloudy } \\
\text { days, which extends the working life } \\
\text { of the battery } \\
\text { - Battery types evaluated over cost, } \\
\text { energy density, deep discharge } \\
\text { tolerance, self-discharge rate, toxicity } \\
\text { and other parameters; nickel-metal } \\
\text { hydride (NiMh) was deemed most } \\
\text { appropriate } \\
\text { - AA form factor is nonproprietary, } \\
\text { available globally } \\
\text { - Single battery avoids user } \\
\text { uncertainty in replacement } \\
\text { - Battery lifespan = 50\% capacity } \\
\text { after } 500 \text { cycles }\end{array}$ \\
\hline LED & $\begin{array}{l}\text { - Efficacy (lumens-per-watt) is } \\
\text { significant factor in overall product } \\
\text { performance } \\
\text { - LEDs typically designed to run in } \\
\text { specific power range } \\
\text { - Lower-quality LEDs can have } \\
\text { significant variations in performance } \\
\text { and color9 } \\
\text { - Color temperature can be an issue- } \\
\text { cooler white is cheaper than warm } \\
\text { white for the same light output; user } \\
\text { preferences may depend on } \\
\text { familiarity with fluorescent lighting }\end{array}$ \\
\hline Circuitry & $\begin{array}{l}\text { - Energy-efficient design is critical } \\
\text { for low-power application }\end{array}$ \\
\hline
\end{tabular}

- Selection of LED driver / integrated circuit changes efficiency

- Circuit should deliver constant current for optimal LED operation 10

- $\quad$ Single-sided PCB reduces fabrication costs, but total surface area is more significant

- Switch quality is important, especially given various environmental conditions

\begin{tabular}{|l|l|}
\hline $\begin{array}{l}\text { External } \\
\text { wiring }\end{array}$ & $\begin{array}{l}\text { - Sufficiently small resistance for } \\
\text { low-power DC current } \\
\text { - Molded connector with appropriate } \\
\text { grab strength and durability }\end{array}$ \\
\hline $\begin{array}{l}\text { Case and } \\
\text { packaging }\end{array}$ & $\begin{array}{l}\text { Injection-molded plastic housing } \\
\text { with removable cover } \\
\text { - Simplified geometric case design } \\
\text { has lower tooling cost, additionally } \\
\text { this minimizes material usage for } \\
\text { lower per-unit costs and shipping } \\
\text { costs } \\
\text { Simple cardboard box with paper } \\
\text { insert }\end{array}$ \\
\hline
\end{tabular}

Conclusion: Photovoltaic technology is a type of renewable energy that is always available and free. Solar home system technology offers the epitome of sustainable development. If implemented correctly, it will begin to lift rural communities out of poverty in an environmentally friendly way. After all this is taken into consideration, seed funding will need to be acquired from social investors, another significant hurdle. This benefits local economies and creates a positive feedback cycle that can work to light up the darkness for millions of the world's poor.

Acknowledgement: This article is based on a review of the solar PV based rural electrification efforts in the Hyderabad region, conducted as part of the research project titled 'Rural Electrification bu Solar Power LED's' The author acknowledges the funding support provided to the research project by the Department of Science and Technology.. I would also like to thank to Mr. J..Nagasewara Reddy for his valuable comments and suggestions which helped to improve the manuscript. Authors of the reference materials are also gratefully acknowledged. 
International Journal of Trend in Scientific Research and Development (IJTSRD) ISSN: 2456-6470

\section{References:}

1. The Remote Village Electrification Programme in India: Assessment of Experience in Odisha, Madhya Pradesh and Chhattisgarh, National Council of Applied Economic Research, A project report submitted to Ministry of New and Renewable Energy, 2010.

2. AEPC, 2011. Energy Sector Assistance Programme (ESAP II) Draft Annual Progress Report; Alternative Energy Promotion Centre, Government of Nepal < http://www.aepc.gov.np/images/pdf/jul10jun11.pdf> accessed on August 16, 2012

3. AEPC, 2012. Solar Energy Program in Nepal (private communication from Assistant Director, AEPC, Nepal), Alternative Energy Promotion Centre, Government of Nepal, Kathmandu.

4. Anam, A M B, 2012. Off-grid rural electrification - Bangladesh perspective; In workshop on offgrid access system in South Asia; < http://www.oasyssouthasia.info/docs/oasyssouthas ia_Jan2012_ppt2.pdf> accessed on August 16, 2012.

5. Aulich, H.A., Raptis, F., Schmid, J., 1998. Rural electrification with photovoltaic hybrid plants state of the art and future trends. Progress in Photovoltaics: Research and Applications 6, 325339.
6. Bhandari, $R$ and Stadler, I, 2009. Electrification using solar photovoltaic systems in Nepal. Journal for Applied Energy. 88 (2), 458-465.

7. Chakrabarti, S and Chakrabarti, S. 2002. Rural electrification programme with solar energy in remote region - a case study in an island. Energy Policy; 30:33-42.

8. Chaurey A, Krithika PR, Palit D, Rakesh S, Sovacool BK, 2012, New partnerships and business models for facilitating energy access, Energy Policy 47, 48-55.

9. IDCOL, 2012. IDCOL Solar Energy Program. Infrastructure Development Company Limited, Dhaka, , last viewed September 20, 2012

10. Mainali, B and Silveira, S, 2012. Renewable energy markets in rural electrification: Country case Nepal. Energy for Sustainable Development 16, 168-178.

11. Palit D., Sarangi GK.,2011. A Comparative Analysis of the Solar Energy Programs for Rural Electrification: Experiences and Lessons from South Asia; In proceedings of third international conference on addressing climate change for sustainable development through upscaling renewable energy technologies.

12. Wong, S. 2010. Overcoming obstacles against effective solar lighting interventions in South Asia, Energy Policy 40, 110-120. 